DOI: https://doi.org/10.32839/2304-5809/2020-1-77-17

UDC 373.5.04:316.61

Kazachiner Olena, Zhadan Olena

H.S. Skovoroda Kharkiv National Pedagogical University

\title{
FORMING LIFE VALUES OF CHILDREN WITH SPECIAL EDUCATIONAL NEEDS
}

Summary. The article describes the specific features of forming life values of children with and without special educational needs. There are some themes on children's values and needs: a sense of belonging with peers, opportunities for play, creative activities, and thinking, experiences of speed, excitement, and physical challenges, elements of coziness, withdrawal and comfort for recreation, feeling safe, experience growth in knowledge and understanding of the world, feeling free and autonomous, comforting objects and bonds with home and family, connection with nature. Values-based education of children with special educational needs works through: 1) values consciousness; 2) wellbeing; 3) agency; 4) connectedness; 5) transformation; 6) achievement. Spiritual, social, moral and cultural values are taught in assemblies and in discreet lessons but also permeate the whole of the curriculum.

Keywords: values, needs, life values, children with special educational needs, upbringing, wellbeing, development.

Казачінер О.С., Жадан О.M. Харківський національний педагогічний університет імені Г.С. Сковороди

\section{ФОРМУВАННЯ ЖИТТЕВИХ ЦІННОСТЕЙ У ДІТЕЙ З ОСОБЛИВИМИ ОСВІТНІМИ ПОТРЕБАМИ}

\begin{abstract}
Анотація. У статті описано специфічні особливості формування життевих цінностей дітей з особливими освітніми потребами та без них. Існують деякі теми щодо цінностей та потреб дітей: почуття належності до ровесників, можливості для гри, творчої діяльності та мислення, переживання швидкості, хвилювання та фрізичних викликів, елементи затишку, відмови та комфорту для відпочинку, почуття себе в безпеці, переживання набуття знань та розуміння світу, почуваючи себе вільним та автономним, наявність комфортних предметів та зв'язків із домом та родиною, зв'язок із природою. Ціннісне навчання дітей з особливими освітніми потребами працюе через: 1) ціннісну свідомість; 2) благополуччя; 3) сприяння; 4) зв'язок; 5) трансформацію; 6) досягнення. Навчання духовних, соціальних, моральних та культурних цінностей відбуваеться на уроках та позакласній діяльності, але також пронизуе всю навчальну програму. Роль формування життевих цінностей у дітей з особливими освітніми потребами велика, оскільки це сприяе профілактиці правопорушень, дозволяе формувати ціннісні оріентири та моральні риси такої дитини, дозволяючи їй органічно вписатися в суспільство; розкриває творчий потенціал, розширюючи можливості професійного вибору; формуе наполегливість у праці, сприяе підвищенню професійної орієнтації, сприяє зниженню кількості безробітних, виховує працелюбність, формуе у свідомості дитини поняття праці як загальнолюдської цінності; дозволяе скоротити кількість неблагонадійних родин; дозволяе розв'язати проблему соціального інфрантилізму. На основі власного педагогічного досвіду роботи з учнями молодшого шкільного віку, серед яких були ті, що мали особливі освітні потреби, а також викладацької роботи з учителями початкових класів у системі післядипломної освіти було визначено такі форми, методи та прийоми забезпечення духовного розвитку таких школярів: На уроках: нетрадиційні уроки; читання та аналіз творів дитячої художньої літератури; у позакласній діяльності: перегляд, аналіз та обговорення змісту мультиплікаційних фрільмів, які навчають дитину толерантності; перегляд, аналіз та обговорення художніх фільмів для дітей; бесіди; тренінгові заняття; виховні заходи години спілкування; краєзнавча пошукова робота та інші.
\end{abstract}

Ключові слова: цінності, потреби, життеві цінності, діти з особливими освітніми потребами, виховання, розвиток, благополуччя, розвиток.

Droblem statement. Nowadays situation is that a great amount of children with special educational needs come to kindergartens and schools. All these children need to be socialized in our society. That is why forming their life values is necessary for education, upbringing and development of such children.

Children who have special educational needs can have many similar experiences compared with children without such special needs, but they can also have different experiences compared with their peers.

Understanding how children experience life in educational settings should be an imperative for educational practitioners, evaluators, and researchers. Listening to children's points of views would facilitate the development of educational settings that meet the needs of children and contribute to their wellbeing and development so that their experiences are both joyful and meaningful. These aspects are discussed and linked to educational evaluation models and theories of values and needs.

Analysis of the latest research and publications. There are a number of studies and evaluation tools that describe the needs of children, both with and without special educational needs, suggest optimal conditions for their wellbeing and development, and provide advice on how to develop high-quality educational environments.

There are a number of studies and evaluation tools that describe the needs of children, suggest optimal conditions for their wellbeing and development, and provide advice on how to develop high-quality educational environments. For exam- 
ple, A. Westling [8], J. Einarsdottir [1], G. KraghMüller and R. Isbell [3], and N. Wiltz and E. Klein [10] have investigated the perspectives of children on their education reporting that children need to experience stimulating educational activities, to build friendships, and to play with peers to be able to thrive. Further, children want opportunities to choose what to do. Conversely, children found to be negative peers' mean behaviour, unstimulating activities, and lack of autonomy.

T. Harms, R. Clifford and D. Cryer [2] investigated what constitute optimal conditions for children's wellbeing and development in preschool settings, and reported that children need to have furnishings for relaxation and comfort; spaces for privacy; spaces for gross and fine motor play; lots of equipment to practise their gross and fine motor skills; spaces for block building; sand and water for play; a safe setting; positive and warm interactions with staff and peers; free time; opportunities to explore nature and learn more about culturally relevant topics and subjects - for example, math, reading and writing. These elements have been structured in a descriptive model, the Early Childhood Environment Rating Scale - Revised, which can be used as a tool for the evaluation of early years learning environments.

E. Soukakou $[4 ; 5]$ investigated what constitute optimal conditions for children's wellbeing and development, with attention given to the adaptations and the support that should be provided in inclusive educational environments, for children with special educational needs. E. Soukakou's model, the Inclusive Classroom Profile, identifies these elements: adaptations of space, materials and equipment; adult involvement in peer interactions; adults' guidance of children's free-choice activities and play; conflict resolution; membership; relationships between adults and children; support for communication; adaptation of group activities; transitions between activities; positive and warm feedback; family-professional partnership; and monitoring children's learning. The ICP can be used as a tool for the evaluation of inclusive early years learning environments $[4 ; 5]$.

The aim of the article is to describe the specific features of forming life values of children with and without special educational needs.

The principal material statement. In order for the school's purpose to be effective and for the values to be meaningful to the pupils, the staff understand that the basic needs of children are: to be loved; to feel secure and know clearly what is expected of them; to be valued; to have a balance of activities - active / passive; quiet / talking; communicating / reflective; taught skills / exploratory work; to have help to develop relationships; to develop self-awareness and a knowledge of the world outside of themselves; to have creative experiences, including external exploration and internal reflection; to be fully involved in the process of education [6].

On the base of research [7] there are some themes on children's values and needs: a sense of belonging with peers, opportunities for play, creative activities, and thinking, experiences of speed, excitement, and physical challenges, elements of coziness, withdrawal and comfort for recreation, feeling safe, experience growth in knowledge and understanding of the world, feeling free and autonomous, comforting objects and bonds with home and family, connection with nature.

In order to try to meet the needs of children, we should always to be consistent in our own behaviour and in expectations of the children. They are the following [6]: value all the children, display great patience and listen carefully to children, focus on and emphasize the positive, face reality and help pupils to come to terms with difficult issues as they arise, such as death, only disapprove of poor behaviour, never the child, try to make time for one another, are mutually supportive, speak quietly and avoid shouting, are valued by the governors and the community, have a good sense of humour, communicate with parents to ensure that they appreciate the school's values and to ensure that there is a common understanding.

Values-based Education works through [6]:

- Values Consciousness. Teachers think more deeply about their teaching and the values that they model both in and outside of the classroom. Pupils report how a values consciousness impact on their behaviour and actions, which become more altruistic.

- Wellbeing. In thinking about and enacting values, students develop self-worth, empathy and responsible personal behaviour. Evidence shows that Values-based Education has a very positive effect on pupils who are 'at risk', marginalized or disadvantaged. There is compelling evidence that the impact of wellbeing is experienced by teachers, parents and families, in classrooms and across whole schools.

- Agency, what is the capacity of individuals to be self-led, to act independently, to make choices and act on them. The evidence shows that Values-based Education strengthens pupil agency when it involves various forms of giving, outreach and working in the community. For instance, through values action projects that allow students to enact their values in a way that is personal, real and deeply engaging.

- Connectedness. Values-based Education builds positive and wide-ranging connections between teachers, pupils and parents. It supports pupil engagement in learning, improves parent engagement in their children's learning and allows teachers to develop new relationships with their pupils, each other and the parents and families in their school community. This is done through shared goals and practices in Values-based Education, which leads to the development of mutual feelings of respect, trust and safety; and varied opportunities for collaboration. The research findings show that the values lead to improved behaviour in the classroom, school and home.

- Transformation. Change and transformation are at the heart of Values-based Education and is the result of teachers and pupils being urged to engage in continuous reflection on the actions they implemented in their schools. Key changes are seen in professional practice as well as personal attitudes, behaviours, relationships and group dynamics. Transformations are experienced and observed by teachers, pupils and parents alike. The data points to profound transformations in pupil learning. Pupils develop deeper understanding of complex issues and how these pertain to their own lives. Pupils and parents experience personal change and report changes seen in others. 
- Achievement. As a result of the above, many schools report improvements in a wide range of individual achievement and academic attainment. Pupils report a deeper engagement in and connection to their learning and demonstrate an understanding of the responsibilities this entails for themselves and others.

When working on the problems of children with special educational needs' life values formation, their age and pedagogical features should be taken into account:

1. Addiction to the game. In terms of game relationships, the child voluntarily practices, assimilates normative behavior. In games for a child, the rule is required. So the child learns to reckon with others, receives lessons of justice, honesty, truthfulness.

2. Inability to engage in monotonous activity for a long time.

3. Lack of clarity on moral perceptions due to little experience. Considering the experience of children, moral standards can be divided into 3 levels: a child under 5 learns the primitive level of rules based on prohibition or denial: "Do not speak too loudly", "Do not interrupt those who speak", "Do not touch other people's things", "Don't throw garbage" and more. There is no point in talking about the second level of moral education unless the first is mastered. But it is precisely this dispute that is observed among teenagers: they want to please the people around them, but have not mastered the elementary correct behavior. At 3 levels (up to 14-15 years) teenagers master the principle: "Help those who are around you!"

4. There may be a dispute between knowledge, as it should be, and practical application (this applies to etiquette, good faith rules, communication).

We believe that in organizing the process of spiritual and moral education of children with SEN and improving its effectiveness, the basic principles that underpin inclusion must be taken into account: the value of a person does not depend on their abilities and achievements; everyone is capable of feeling and thinking; everyone has the right to communicate and to be heard; all people need each other; genuine education should only take place in the context of real relationships; all people need peer support and friendship; diversity enhances all aspects of human life.

Spiritual, social, moral and cultural values are taught in assemblies and in discreet lessons but also permeate the whole of the curriculum [8].

However, the complication of the problem of moral education, including the spiritual development of children with special educational needs is determined by:

1. lack of research on the topic of moral education of children with OOP, as there are no special programs in the given direction (namely for children with special educational needs);

2. children with special educational needs have different disorders of psychophysical development. In a child, due to the transmitted diseases, the normal course of the processes of perception, remembering, and reproduction are disturbed.

Many students are characterized by the presence of serious excitation disorders, unbalanced behavior. The abnormal functioning of these processes does not allow the child to acquire a complex system of knowledge about the world.
Basing on own pedagogical experience of working with primary schoolchildren including the ones with special educational needs and experience of working with primary school teachers in the system of postgraduate education we singled out such forms, methods and ways of forming life values of children with SEN:

1) At the lessons:

- providing non-traditional types of lessons (lessons of kindness, lessons of good behavior etc.);

- reading literature stories for children (fairytales by V.Sukhomlynsky "The Seventh Daughter", "A kind word", "Strawberries for Natalia" "A Glass of Water", "An apple in an autumn garden", V. Kataev's story "Rainbow Flower", V.Nestaiko "Zhora Horobeiko's crime", N.Krasotkina "A Star", "Ivasyk draws a Rain" etc.)

2) During out-of-class activities:

- watching, analysis and discussion of the content of cartoons, which teach tolerance ("A Gift", "My Brother is from the Moon", "About Dima", "Tamara" etc., norms of moral behavior ("The Key", "The Tale of Old Oak", "A Yellow Stork" etc.),

- watching, analysis and discussion of films for children ("The Scarecrow", "The Granny's Grandson" etc.),

- dialogues, conversations ("Harmful Habits", "Spiritual Health", "We Learn to See a Beauty", "Seven Colours of Happiness" etc.);

- training sessions: "Country of Kindness", "What is good, what is bad", "You live among people", "Friendship class is strong" and others; educational activities: "I believe in the power of kindness", "Learn to live in friendship", "Kindness is the beauty of the human soul", "To be human on Earth", "Magic words", "Say NO" to bullying", "Words of Congratulation and Farewell", "Honesty and Truth", "Honor People - and They Will Respect You", "Bring good to the world of nature", "Magic words open hearts" and others;

- hours of communication: ("Easter bells" and others);

- regional research work ("Color of our country's nationalities" and others).

Conclusions. Therefore, at the end we come to conclusion that values-based education of children with special educational needs works through: 1) values consciousness; 2) wellbeing; 3) agency; 4) connectedness; 5) transformation; 6) achievement. Spiritual, social, moral and cultural values are taught in assemblies and in discreet lessons but also permeate the whole of the curriculum.

There are some themes on children's values and needs: a sense of belonging with peers, opportunities for play, creative activities, and thinking, experiences of speed, excitement, and physical challenges, elements of coziness, withdrawal and comfort for recreation, feeling safe, experience growth in knowledge and understanding of the world, feeling free and autonomous, comforting objects and bonds with home and family, connection with nature.

The main contribution of the present study is that it increases the knowledge and understanding of matters that the children in the context investigated valued and needed in order to experience wellbeing and development during their early school years. 


\section{References:}

1. Einarsdottir, J. (2008). Children's and parents' perspectives on the purposes of playschool in Iceland. International Journal of Educational Research, 47(5), 283-291.

2. Harms, T., Clifford, R.M., \& Cryer, D. (2005). Early childhood environment rating scale-revised edition. New York: Teacher's College Press.

3. Kragh-Müller, G., \& Isbell, R. (2011). Children's perspectives on their everyday lives in child care in two cultures: Denmark and the United States. Early Childhood Education Journal, 39(1), 17-27.

4. Soukakou, E.P. (2012). Measuring quality in inclusive preschool classrooms: Development and validation of the inclusive classroom profile (ICP). Early Childhood Research Quarterly, 27(3), 478-488.

5. Soukakou, E.P. (2016). Inclusive classroom profile. ICPTM (Manual Research ed.). Baltimore, MD: Paul H. Brookes.

6. Values-based Education. URL: https://www.ledbury.hereford.sch.uk/values-based-education/

7. Values and Needs of Children With and Without Special Educational Needs in Early School Years: A Study of Young Children's Views on What Matters to Them. URL: https://www.tandfonline.com/doi/full/10.1080/0031383 1.2018.1466360

8. Values \& SMSC Policy. URL: http://www.swindonvillage.co.uk/Uploads/SVPS/Policies/Values\%20and\%20SMSC \%20Policy\%202017.pdf

9. Westling Allodi, M. (2010). Goals and values in school: A model developed for describing, evaluating and changing the social climate of learning environments. Social Psychology of Education, 13(2), 207-235.

10. Wiltz, N.W., \& Klein, E.L. (2001). What do you do in child care? Children's perceptions of high and low quality classrooms. Early Childhood Research Quarterly, 16(2), 209-236. 